УДК 94(47).065

\title{
РОССИЙСКИЕ ПЛАНЫ УСИЛЕНИЯ РЕЧИ ПОСПОЛИТОЙ В 1746 Г.: ПОЛЬСКАЯ МИССИЯ М. ЛИВЕНА И М.Н. ВОЛКОНСКОГО
}

\author{
(c) 2020 М.Ю. Анисимов \\ Институт российской истории РАН, г. Москва \\ Статья поступила в редакцию 26.10.2020
}

\begin{abstract}
В 1746 г. в Речи Посполитой должен был быть созван очередной сейм, на котором польский королевский двор решил провести решение об увеличении польской армии, ограниченной еще во время Северной войны. Одной из главных причин появления этого плана было усиление Пруссии, что грозило силовой аннексией Берлина западных польских территорий. В Петербурге, где правительство Елизаветы Петровны также было озабочено ростом могущества Пруссии, решили поддержать польские планы, превратить Польшу в союзника России в антипрусской борьбе. Для этого для подготовки польских магнатов и выяснения возможностей организации пророссийской партии в Польшу были отправлены русские эмиссары М. Ливен и М.Н. Волконский. По возвращении в Россию эмиссары сообщили, что, несмотря на опасения пруссаков, поляки не готовы предпринимать какие-либо провоцирующие их шаги, в том числе и увеличение армии. Также эмиссары представили кандидатуры магнатов, способных быть активными сторонниками России. С этого времени русский двор, отказавшись от идеи усиления Речи Посполитой, больше не упускал из виду внутриполитическую ситуацию в Польше и поддерживал ориентировавшуюся на сближение с Россией влиятельную группировку князей Чарторыйских. Ключевые слова: Елизавета Петровна, внешняя политика России, Речь Посполитая.
\end{abstract}

DOI: 10.37313/2658-4816-2020-2-4-79-92

Вопросы российско-польских отношений первых лет правления Елизаветы Петровны не получили должного освещения в историографии. В России их исследовал C.M. Соловьев в многотомной общей истории России, в польской историографии начала XX века - В. Конопчиньский. В современной Польше вопросами российскопольских отношений в 40-е гг. XVIII в. занималась 3. Зелиньская.

3. Зелиньская в своей отдельной работе посвятила много страниц русской политике в отношении польских планов 1744 г. об увеличении польской армии, стремясь оспорить утверждения С.М. Соловьева, представителей немецкой (В. Медигер, М. Мюллер), а также польской историографии (С. Ашкенази, М.

Анисимов Максим Юрьевич, кандидат исторических наук, старший научный сотрудник.

E-mail:anisimovm@list.ru
Скибиньский, В. Конопчиньский) о том, что Петербург поддержал тогда эти польские планы $^{1}$. Польский историк утверждает, что Россия, как и Пруссия, хотела сорвать этот сейм и не допустить решения об увеличении польской армии, объявляя прямые рескрипты об этом русским посланникам «мнимыми», т.е. призванными обмануть польский двор, используя трактование фактов удобным образом. В целом разбор аргументации 3. Зелиньской, которая всеми силами стремится найти подтверждение своей уже готовой теории в источниках, а не выстраивает теорию из источников, заслуживает отдельной работы.

3. Зелиньская рассматривает документы времен сейма 1744 г. и не рассматривает документы последующих лет, в которых русский двор не только словесно поддерживает польские планы увеличения армии, но и действует в этом направлении. 
Такая поддержка России проявила себя всего через 2 года, в преддверии следующего созыва сейма, в 1746 г. В фонде «Сношения России с Польшей» Архива внешней политики Российской империи есть малозаметное дело «Отправление в Польшу и Литву бригадира Ливена и генерал-адъютанта Волконского». В этом деле нет записей о предыдущих просмотрах историками, нет упоминаний об этих документах и об этой миссии и в исследовании С.М. Соловьева - он достаточно часто оставлял в стороне второстепенные дела (хотя в них могли находиться и важнейшие документы), ограничиваясь основными - официальной дипломатической перепиской. Три документа этой миссии (указы Елизаветы Петровны за подписью Бестужева-Рюмина двум русским эмиссарам) были опубликованы в «Русском архиве» ${ }^{2}$, но в них нет ни слова о цели миссии и составлены они так, чтобы читающий их ничего не понял о сути миссии. Опубликованный дневник М.Н. Волконского тоже описывает эту миссию, не говоря о ее цели и только фиксируя перемещения Волконского по Речи Посполитой ${ }^{3}$.

Матвей Григорьевич (Маттиас Эберхард) Ливен в юности служил в армии польского короля и саксонского курфюрста Августа II, после чего перешел на службу в русскую армию, и в 1731-1732 гг. был адъютантом российских представителей в Варшаве. Когда началась война за Польское наследство, Ливен, как человек, прекрасно знающий польские дела, снова был командирован в Речь Посполитую и находился там всю войну вплоть до коронации Августа III. В русско-турецкую войну 1735-1739 гг. Ливен с 1739 г. снова оказался в Польше, занимаясь переговорами с польскими магнатами, где затем был одним из русских комиссаров по урегулированию претензий польских дворян по поводу прохода русской армии Миниха через Польшу. В 1741 и 1742 гг. Ливен снова направлялся в Польшу для переговоров с магнатами, и теперь его ждало новое поручение.
Князь Михаил Никитич Волконский в 1733 г., когда ему было 20 лет, был в составе российского посольства Левенвольде в Речь Посполитую, затем отправился волонтером на осаду Гданьска. В 1739 г. он также ездил вместе с М. Ливеном «для некоторой комиссии» ${ }^{4}$ в Польшу, для чего ездил в польском мундире, раздавая полякам некие печатные прокламации. В 1746 г. Волконский состоял в качестве генерал-адъютанта (это должность, по чину Волконский был премьер-майор) при российском фельдмаршале Ласси и был направлен в Польшу в паре с Ливеном. Волконский был родным племянником влиятельного главы русской дипломатии канцлера А.П. Бестужева-Рюмина и его старшего брата - дипломата и обер-гофмаршала М.П. Бестужева-Рюмина, тогдашнего российского посланника при польско-саксонском дворе.

Обстоятельства отправки эмиссаров были следующими. Во Второй Силезской войне (1744-1745 гг.) Фридрих II, нарушив Бреславльский мир с австрийской государыней Марией Терезией, атаковал ее владения. Саксония в этой войне была союзником Австрии, а 1745 г., в ответ на перенос австрийцами и саксонцами войны из австрийской Богемии в прусскую Силезию, присоединенную к Пруссии в результате Первой Силезской войны 17401742 гг., Фридрих II 14 (25) августа 1745 г., разбив союзников в Силезии, вторгся в Саксонию. В Петербурге объявили об оказании военной помощи саксонскому курфюрсту и одновременно польскому королю Августу III. Оказать помощь, впрочем, не успели, так как Фридрих II уже заставил своих врагов подписать мир в занятой им саксонской столице Дрездене 14 (25) декабря 1745 г.

Хотя Фридрих II вернул Саксонию Августу III, императрица Елизавета Петровна была недовольна этим миром - непобедимую Пруссию надо было остановить, надеясь на любой повод для возобновления войны в Европе. 4 января 1746 г. рос- 
сийская императрица поручила составить план возможных военных операций ${ }^{5}$. Далее было «докладывано, что как и словесно пред сим е. и. в. от канцлера всеподданнейше представлено было, весьма нужно ныне в Польшу, для разведывания о склонностях и сентиментах тамошних магнатов и для приведения их, при нынешних критических обстоятельствах, к полезнейшим для здешних интересов мерам (чтобы тамо по французским и прусским проискам конфедерации противу короля для возведения Станислава Лещинского или принца Контия не возбудили), нарочных эмиссаров послать», и предложить отправить генерал-майора Юрия Ливена, его брата полковника Матвея Ливена и генерал-адъютанта Волконского, повысив Ливенов «для лучшего куражу» новыми чинами (М. Ливен получил чин бригадира, Ю. Ливен остался в Гдань(ке) $)^{6} .7$ января Елизавета, констатировав заключение мира между Пруссией и Саксонией, поставила перед своими советниками новую задачу - выработать план дальнейших предосторожностей против Фридриха II 70 января Елизавета Петровна сама напомнила канцлеру об отправке Ливенов и Волконского в Польшу ${ }^{8}$

24 февраля кабинет-секретарь императрицы барон И.А. Черкасов отправил записку канцлеру Бестужеву-Рюмину, в которой сообщил, что сегодня к фельдмаршалу Ласси был отправлен указ о воинских магазинах, и Елизавета Петровна велела ему передать канцлеру «отправлять бригадира Ливена и князя Волконского, ибо ведомостями, присылаемыми от графа Ласси, недовольна, да и не будет пути без своих людей» ${ }^{9}$. Смысл фразы неясен (не идет ли речь о пути русского корпуса против Пруссии?), очевидно только нетерпение императрицы (которую традиционно представляют ленивой и не желающей заниматься делами) и стремление скорее отправить эмиссаров столь важной для нее миссии.

Свежеиспеченный бригадир Ливен подал канцлеру свое мнение о миссии, в ко- тором сообщил, что не был в Польше уже три года и не знает позиции магнатов по отношению к России. В письмах к магнатам без указания их имен, по замечанию Ливена, нужно писать «ваша мости» («ваша мосць» - «ваша милость»), а не просто «вам», «вы», так как это «тамошним господам весьма противно есть» ${ }^{10}$, и может ли Ливен обещать польному гетману коронному Браницкому пост великого гетмана коронного после смерти нынешнего великого гетмана?

26 февраля Елизавета Петровна снова на устном докладе канцлера спросила его о том, не пора ли отправлять в Польшу Ливена и Волконского, и снова распорядилась: «токмо немедленно его с потребными наставлениями отправлять» ${ }^{11}$.

Но канцлер не торопился. Только 14 марта он представил императрице проект инструкции Ливену и Волконскому и проект писем трем магнатам, к которым и отправлялись эмиссары, - коронному маршалу Мнишеку, коронному великому гетману Потоцкому и литовскому маршалу Сангушко, которые в 1745 г. передали с русским эмиссаром Ф. Даревским письма к канцлеру Бестужеву-Рюмину и общий мемориал с предложением «о ближайшем и теснейшем е. и. в. с Республикою Польскою соединении и ненарушимой дружбы утверждении» и просьбами защиты Речи Посполитой от недоброжелательных держав. Эмиссары должны были повезти ответ из Петербурга, что Елизавета Петровна согласна с предложениями магнатов и готова оказать любое свое содействие их стараниям на сейме, созываемом в этом году. Способы реализации общих планов российская императрица предлагает следующие: 1) присоединение Речи Посполитой к союзному договору России и Саксонии, 2) признание Речью Посполитой императорского титула Елизаветы Петровны и 3) «умножение коронной армии».

Третий пункт особенно важен для русско-польских отношений. Неудивительно, что на этот пункт обратил внимание и пу- 
бликатор «Архива князя Воронцова» П.И. Бартенев, отметивший в примечании к нему: «Такова была в то время еще чуждая прусского влияния политика России» ${ }^{2}$. 3. Зелиньская опровергает любое положительное, даже нейтральное отношение России к увеличению коронной армии, сокращенной решением «Немого сейма» 1717 г., превратившего Речь Посполитую в фактический протекторат России ${ }^{13}$. Даже прямые инструкции о нейтралитете России в отношении польских планов увеличения армии она стремится толковать как отрицательные, считая все эти инструкции ложными. 3. Зелиньская считает русскую политику в отношении Польши неизменной, не принимая в расчет ее зависимость от изменений системы международных отношений в Европе. А в Европе в начале 40-х гг. XVIII в. стремительно усилилась Пруссия, превратившись из второразрядного германского курфюршества в новую великую державу, опасную всем соседям. Даже прежде мощная Австрийская монархия была побеждена прусским королем Фридрихом II в двух Силезских войнах, Саксония была ею полностью разгромлена. Магнаты и шляхта Речи Посполитой тоже осознали, что если Фридрих II захочет присоединить к своему государству какие-то части Польши, то польских сил не хватит, чтобы этому помешать, и помочь может только Россия, а не далекая Франция, проигравшая войну за Польское наследство, не бессильная Саксония и не поверженная Австрия. По этой причине многие магнаты, поддерживавшие в 17331735 гг. Станислава Лещинского, боровшиеся против русского влияния, теперь, как тот же коронный гетман граф Иосиф Потоцкий, стали искать поддержки России. Петербург воспринимался в Польше как сосед, не желающий ее раздробления и поглощения, единственный способный защитить республику от Пруссии.

Возвышение Пруссии вызвало изменения и в политике правительства Елизаветы Петровны. С 1745 г. она становится резко антипрусской, что в итоге приведет Россию в Семилетнюю войну 1756-1763 гг. против Пруссии. Изменяется и отношение России к увеличению польской армии, которая была сокращена по воле Петра I, и с тех пор Россия всегда придерживалась его политики. Теперь увеличенная армия Польши должна была быть способной если и не защитить республику от армий Фридриха II, то по крайней мере продержаться до подхода на помощь русской армии. Первый пункт изложенного выше плана Елизаветы Петровны предполагал и присоединение Речи Посполитой к союзу Саксонии и России, что тоже было вызвано стремлением использовать польские силы против Фридриха II. Возможно, именно надежда превратить Польшу в союзника по борьбе с Пруссией и вызвала то нетерпение, продемонстрированное Елизаветой Петровной в отправке миссии Ливена и Волконского.

Одобренные императрицей инструкции эмиссарам с печатью и подписью Бестужева-Рюмина были вручены им 20 марта и, по возвращении обратно в Россию, 8 января 1747 г. переданы Ливеном и Волконским в Коллегию иностранных дел и затем отправлены в архив. Поэтому в бумагах Волконского публикаторы и не обнаружили других документов этой миссии, кроме трех указов императрицы, отправленных уже в ответ на их донесения из Польши.

В самих инструкциях говорилось, что в связи с напряженной международной обстановкой необходимо «на все происхождении, и как на внутренние, так и чужие интриги и предвосприятия смотреть» и предостерегать российские интересы в Польше - «о целости и ненарушимости соблюдения вольности» и стремиться склонять поляков к России.

Особая роль Польши в планах Петербурга, подчеркивалось в инструкции, связана с тем, что прусский двор, получив Силезию, «во усиление приходить стал», и старается как у других держав, так и особливо в Польше (...) сильную инфлюенцию 
возыметь», привлечь поляков на свою сторону. Особо сильной такая попытка была в 1744 г., во время предыдущего сейма, когда прусский король стремился вызвать в Польше конфедерацию, предлагая польский трон, например, магнату Яну Тарло, который сам признался в этом Августу III. Этот сейм «замешательствами в ничто обращен и без всякого плода республике разорван».

После этого, разгромив в войне Саксонию, Фридрих II усилился еще больше, многие в Польше это поняли и готовы были встать на его сторону, создав особую партию. Прусские цели в Польше инструкция Бестужева-Рюмина характеризовала как «Польшу от него зависимою учинить», в союзе с Францией лишить Августа III польской короны и передать ее или Станиславу Лещинскому, или кузену французского короля принцу Конти («о чем недавно слышно было», как отметил канцлер в скобках), а также оторвать от Польши какие-то территории - прежде всего Польскую Пруссию, об этом стремлении овладеть провинцией знает вся Европа. По разным известиям, пруссаки разглашают в Речи Посполитой, что Фридрих II готов взять под защиту Курляндию, освободив ее от русской зависимости, и утвердить на герцогском престоле в Митаве одного из своих братьев или своего шурина принца Фердинанда Брауншвейгского.

Интересы России, по мысли канцлера, требуют предотвратить такое развитие событий. В 1745 г., когда Август III мог согласиться на избрание его императором Священной Римской империи и, следовательно, покинуть польский престол, в Петербург обратились три влиятельных польских магната - коронный маршал Иосиф Мнишек, коронный гетман граф Иосиф Потоцкий и маршал литовский князь Павел Сангушко. Магнаты просили русской протекции и выражали желание скрепить русско-польский союз.

Ливену и Волконскому сообщалось, что их миссия и является ответом на это об- ращение трех магнатов. К каждому из них эмиссары везли ответные письма императрицы и канцлера.

Далее, после такого вступления, начиналась сама инструкция из многих пунктов.

Эмиссары должны были вручить указанные письма, для чего они могли разделиться и отправиться к каждому из них отдельно. Трем адресатам писем Ливену и Волконскому можно было назвать свои настоящие имена (они были указаны и в письмах к магнатам от канцлера), остальным магнатам и шляхтичам эмиссары могли назвать и то, что они русские офицеры с важной миссией, и свои имена, только если они знали своих собеседников как «патриотов» и им доверяли. Остальным эмиссары должны были называться разными именами, утверждая, что они польско-литовские офицеры. Помимо писем трем магнатам эмиссары должны были сообщить им устно о том, что цель Елизаветы Петровны - «чтобы Речь Посполитая всегда и при всяких случаях при совершенной своей вольности, конституциях, правах и справедливостях без всякого нарушения или ущербу оной весьма содержана и сохранена была», что Елизавета Петровна их любит и будет рада, если Мнишек, Потоцкий и Сангушко предпримут следующие меры: 1) Будут верными Августу III, который ради Польши отказался от императорской короны, 2) Будут способствовать присоединению Речи Посполитой к союзу Саксонии и России 1744 г., 3) Добьются признания своей страной императорского титула русской государыни и 4) «Чтоб они своими знатными стараниями равномерно и сие заблаговременно к сейму предуготовили, дабы на оном толь давно всеми истинными Речи Посполитой патриотами желаемое и к содержанию внутренней тишины, також для вящей безопасности от иностранных неприятелей весьма потребное умножение коронной армии немедленно в состояние приведено было, яко те опасности, кои нарушению покоя и вольности Речи Посполитой вид подают, не токмо продол- 
жаются, но и преумножаются», особенно со стороны Фридриха II, который сам постоянно увеличивает свою армию. Поляков нужно убеждать, «что все сии обстоятельства необходимо требуют, дабы Република натуральным образом сама о себе попечение имела, и без упущения времени для сохранения вольности и владений своих потребные и к обороне достаточные меры принимала», а Петербург всегда Польше в этом поможет.

Все вышеизложенное эмиссары должны говорить и другим магнатам, и шляхтичам (пункты перечислялись заново), убеждая их, что только Россия может помочь Речи Посполитой бескорыстно. Тем собеседникам, которые преданы Франции и Пруссии, Ливен и Волконский тоже должны были рассказывать те же аргументы, но не как русские офицеры, а как посторонние люди, понимающие интересы Польши и России.

Среди трех магнатов особую политику эмиссары должны были проводить по отношению к гетману Потоцкому, который ранее всегда придерживался антироссийской линии и теперь, как говорят, поддерживает Пруссию. Потоцкому ничего против Пруссии говорить было нельзя, так как он мог передать слова русских официальных лиц Фридриху II, что «излишнюю с здешним двором холодность и ссору возбудить может», поэтому с ним нужно говорить общими фразами про иностранные державы.

В Петербурге не знали, на кого могут опереться как на своих сторонников в Польше, учитывая, что магнаты, давно получавшие русские «пенсии» - князь Я.Т.К. Любомирский, воевода краковский, и князь Н.Ф. Радзивилл, новогрудский воевода умерли. Сторонниками России считались князь А.А. Чарторыйский, воевода русский, князь М.К. Радзивилл, великий гетман литовский, польный коронный гетман граф Я.К. Браницкий, и эмиссарам следовало убедиться в том, что им можно доверять, а также найти и других готовых поддерживать в Речи Посполитой сотрудничество с
Россией. Явно отвечая на ранее заданный Ливеном вопрос, Бестужев-Рюмин сообщил в инструкции, что эмиссары могут обещать Браницкому пост великого коронного гетмана после смерти престарелого Потоцкого.

В целом Ливену и Волконскому следовало внимательно наблюдать за всем, что происходит в Речи Посполитой, бороться разными беседами и уговорами с прусскими, французскими и шведскими интригами, планами конфедераций и разными антироссийскими намерениями, опровергая разные враждебные русским интересам слухи. Отдельным пунктом инструкции была необходимость предупреждения поляков о том, что к Риге из Смоленска по Днепру и Западной Двине, через польские владения, будет отправлен провиант для расположенного в Лифляндии русского корпуса, а после тем же путем пройдут и подкрепления для него. С Ливеном и Волконским отправлялись также 2 офицера и 2 унтер-офицера, а также, по ранее высказанной Ливеном просьбе, 2 плотника ${ }^{14}$.

Письма к магнатам, датированные тем же числом - 17 марта, тоже утвержденные Елизаветой Петровной 14 марта, содержали те же предложения о присоединении Польши к союзу Саксонии и России, о признании императорского титула и об увеличении коронной армии.

Получив инструкции и письма, на следующий день, 21 марта 1746 г., эмиссары отправились в Польшу, по пути в Митаве к ним присоединились офицеры сопровождения.

1 мая они прибыли в Вильну, столицу Великого княжества Литовского, где находилось много литовских магнатов. Эмиссары посетили гетмана князя М. Радзивилла, которого считали одним из главных российских сторонников. Радзивилл доказал это на деле, после официального приема Ливена и Волконского он договорился с ними о тайной встрече. С гетманом, выполняя инструкции, эмиссары не говорили о Фридрихе II, но Радзивилл сам завел о нем речь, утверждая, что, как и все магнаты, боится 
его и считает, что только Россия может защитить поляков от Пруссии. Радзивилл утверждал, что как литовский гетман, то есть командующий войсками Литвы, не допустит в великом княжестве прусских интриг и уже заранее принял для этого нужные меры. На русские предложения о действиях на сейме Радзивилл ответил, что всегда поддерживал Августа III и готов способствовать утверждению союза с Россией, а «с стороны короля прусского меня де ничем не корумпируют» ${ }^{15}$. Кроме того, Радзивилл дал характеристику другим магнатам: его брат, подчаший литовский И.Ф. Радзивилл, уже много лет был с ним в ссоре, гетман считал его сторонником Пруссии, человеком ветреным и не имеющим влияния на шляхту. Зять гетмана, ловчий литовский М.А. Сапега, стоит за французов. Радзивилл не знал, кого поддерживает его заместитель польный гетман литовский М.И. Масальский, но он ранее был сторонником Станислава Лещинского, а теперь, как слышал гетман, получает пенсию от Фридриха II, но поручиться в этом он не может.

Затем Ливен и Волконский посетили виленского католического епископа Михаила Зенковича, которого оценили как сторонника партии короля (таким его охарактеризовал и Радзивилл), «человека доброго и богомольного». Епископ тоже говорил им о том, что вся надежда Польши только на Россию и ему можно верить. Следующими целями визитов русских офицеров стали польный гетман Масальский, ловчий М. Сапега и епископ-коадъютор виленский (заместитель епископа) Иосиф Сапега. Все они ранее были сторонниками Лещинского, но теперь, по словам эмиссаров, перешли на сторону России и сами стали говорить о Фридрихе II - что республика от него в великой опасности и помочь ей может только Россия. Ливен и Волконский подтверждали, что они чрезвычайно осторожны с этими людьми, рассказывая им только о благосклонности к Польше Елизаветы Петровны. Кроме названных магнатов эмиссары могли сообщить, что и вся местная «шляхта к нам склонна и генерально все в страхе от короля прусского, что токмо надежду имеют для целости Речи Посполитой на ее императорское величество» ${ }^{16}$. Донесение, отправленное 9 (20) мая, заканчивалось указанием на то, что один из трех адресатов русских писем, И. Мнишек, уже не коронный маршал, a 3 года как каштелян краковский, то есть первый сенатор, и для письма нужен другой конверт с его новым титулованием.

31 мая Бестужев-Рюмин подписал указ Елизаветы Петровны к эмиссарам, в котором просил их сказать Мнишеку, что отсутствие нынешнего титула не является обидой для магната, и это произошло просто по незнанию, новое письмо с новым титулом может быть тоже отправлено ему ${ }^{17}$.

Ни с Мнишеком, ни с двумя другими адресатами писем эмиссары не встречались, так как их в Вильно не было.

В следующем донесении от 30 мая Ливен и Волконский сообщили, что были с визитом у вдовой княгини Радзивилл, муж которой, Н.Ф. Радзивилл, умер в феврале того года. Барбара Радзивилл говорила, что гетман Радзивилл разослал своим сторонникам распоряжение включить в инструкции поветовых послов на сейм отправку дипломатов-послов к польским соседям, чтобы обновить старые союзы и заключить новые. В соседях Речи Посполитой числились Австрия и Россия, а Фридриха II в Польше воспринимали как «фазала», т. е. вассала республики, потому отправка посла в Берлин не предполагалась.

С точки зрения русских эмиссаров, шляхта может бояться этих планов, так как решит, что ее хотят втянуть в войны. В Вильно Ливен и Волконский видели много шляхтичей и уверенно доложили, что литовская шляхта конфедерации против короля не хочет. «Они к нам больше склонны, нежели к прусской партии, прямой интерес для содержания их в целости понимают», но «по их конфузному правлению и по их несогласию между собой никакого полезного дела для пользы своего отечества произвесть не чаятельно, чтоб могли» ${ }^{18}$. О каких-либо про- 
прусских партиях тут никто не слышал, говорят, их и нет.

В планах эмиссаров был заезд в не столь далекий от Вильно Белосток, где проживал польный гетман Браницкий, а от него Ливен и Волконский планировали разъехаться: Ливен должен был отправиться к Мнишеку и Потоцкому, владения которых находились на юге Речи Посполитой, у молдавских границ, а Волконский - поехать к Сангушко, за Варшаву в Сандомирское воеводство. Вероятно, это ошибка: владениями в Сандомирском воеводстве владел Мнишек, а Сангушко, князь из рода Гедиминовичей, имел родовой дворец в Любартове в Люблинском воеводстве на юге Речи Посполитой, куда направлялся Ливен, который с Сангушко там и встретился. Как бы то ни было, дальше Варшавы Волконский в итоге не поехал.

21 июня уже из Белостока оба эмиссара сообщили, что братья Радзивиллы прекратили свою семилетнюю вражду из-за какой-то деревни и примирились. Иероним Радзивилл говорил с Ливеном и Волконским как «патриот», но эмиссары соблюли инструкции и на всякий случай были с ним осторожны. Патриотами также офицеры посчитали и Огинских. Сообщив о прибытии в Белосток, Ливен и Волконский отметили, что польный гетман всегда был сторонником России и до сих пор, насколько можно судить, не изменил своих взглядов.

Следующее письмо от 28 июня Волконский писал уже один из Варшавы. Он сообщил, что по пути в местечке Браньске (Брянске, как назвал его Волконский и как потом назывался город, когда он стал частью Российской империи, а затем, в 1939-1944 гг., частью Советского Союза) встретил много шляхтичей, которые сами начали говорить ему о своих опасениях по поводу Фридриха $\mathrm{II}^{19}$. В дневнике Волконский тоже отметил, что в Браньске «великое множество было шляхетства» ${ }^{20}$. Вероятно, шляхты было много в Браньске потому, что он был поветовым городом и в нем собиралась шляхта всей Бельской земли для выборов послов на сеймы, как сообщает о польском городе «Брянске» словарь Брокгауза и Эфрона.

3 июля свое донесение из Люблина отправил Ливен. Поездка Волконского в Сандомирское воеводство уже теряла смысл, так как Сангушко оказался на юге Речи Посполитой. Ливен сообщил, что побывал в Любартове у князя Сангушко, который показал себя «добрым патриотом». Сангушко поддержал союз с Россией ради целостности Речи Посполитой. Относительно присоединения Польши к союзу Саксонии и России Сангушко был не столь однозначен, заявив, что этого будет трудно добиться, ведь в саксонско-русском договоре находится гарантия наследования польского престола сыном нынешнего короля. Ливен, судя по его письму, не знал, действительно ли такой пункт внесен в договор, но сомневался в этом, хотя опровергнуть слова Сангушко не мог и не возразил ему. О планах увеличения (аукции) польской армии магнат высказался, что все в Польше хотели бы этого, более того, если на сейме это решение не будет принято, некоторые фамилии (какие конкретно, Сангушко не назвал, как отметил Ливен) готовы организовать конфедерацию при короле, чтобы добиться принятия такого решения. Сангушко попросил Ливена узнать, поддержит ли такую конфедерацию Елизавета Петровна. Относительно признания императорского титула русской государыни магнат не видел никаких затруднений и предложил русскому послу на сейме получить особый диплом. Прусских «факций», то есть партий, в Речи Посполитой нет, уверил Ливена князь ${ }^{21}$.

23 июля канцлер Бестужев-Рюмин отправил Ливену указ Елизаветы Петровны, в котором опровергал утверждения Сангушко о предрешенности Россией наследования польского престола после смерти Августа III ${ }^{22}$.

Через два дня после подписания Ливеном своего письма, 5 июля, донесение из польской столицы отправил Волконский. Он сообщил, что в Варшаву прибыл коронный канцлер Залуский, первое должностное 
лицо Речи Посполитой, которого и посетил русский офицер. В дневнике Волконский отметил, что беседа с канцлером состоялась 1 июля ${ }^{23}$. Из разговора с Залуским Волконский сделал вывод, что поляки, боясь Фридриха II, заигрывают с Россией, чтобы Петербург при возможном нападении на Польшу пруссаков смог ее защитить. Но из-за все тех же страхов перед Фридрихом II поляки не вступят ни в какое соглашение с Россией, чтобы не раздражить этим прусского короля и не дать ему повод для агрессии. Поляки много обещают эмиссарам, но ничего из этого не сделают на деле. Даже планы аукции армии вряд ли будут реализованы - в случае вероятного разрыва сейма принятие решение через большинство на конфедерации будет опасным для Польши, что признают многие поляки - так как в ответ несогласные могут устроить реконфедерацию, на помощь которой тут же придет со своей армией Фридрих II, получив легитимный предлог для вторжения.

Волконский, оговариваясь, что он не знает, что у поляков на сердце, резюмировал: «по моему слабому мнению нахожу, что от здешних хотя и противности к нашей стороне и не воспоследует, однакож и помощи от них при всяком случае не чаятельно, да и для собственной их безопасности не уповаю, чтоб они по своему несогласию между собою и по конфузным их обрядам чтоб что в действо произвели» ${ }^{24}$.

27 июля Ливен доложил, что прибыл в Тарнополь (Тернополь), вотчину гетмана Потоцкого. У Потоцкого Ливен встретил и приехавшего к гетману Мнишека, таким образом, выполнив поручение передать им письма из Петербурга. Оба магната были очень довольны отношением к ним официального Петербурга и уверили, что согласны с тем, что Речи Посполитой нужно быть в согласии с Россией. О планах русского двора оба магната высказались следующим образом: они готовы оказать помощь в присоединении Речи Посполитой к союзу Саксонии и России, готовы признать императорский титул Елизаветы Петровны с условием, чтобы была дана «ассекурация» (обеспечение, от лат. «безопасность»), что императрица не имеет претензий на русские области в составе Речи Посполитой, и готовы, как и все поляки, поддержать планы увеличения польской армии.

Магнаты также предупредили Ливена, что Браницкому не следует во всем доверять, он себе на уме. Прусских «партий» в республике нет, хотя, как говорят, они есть только в Великой Польше.

Ливен также познакомился с сыном коронного гетмана, графом Станиславом Потоцким, воеводой киевским, и решил, что ни хорошего, ни плохого русским интересам от него ждать нельзя, «ибо наиболее пьянством время свое проводит» ${ }^{25}$.

Миссия Ливена и Волконского была выполнена, больше они донесений не отправляли, хотя пробыли в Речи Посполитой еще некоторое время. В своем дневнике Волконский отметил, что 6 сентября он и Ливен были представлены прибывшему в Варшаву королю, а 10 числа обедали у него. 22 сентября открылся сейм, а на следующий день Волконский «для куриозности» (т.е. ради любопытства) посетил заседания Сената и Посольской избы, нижней палаты польского сословного парламента, и в дальнейшем продолжал посещать выступления на сейме, пока 3 ноября сейм бесплодно не завершился.

9 ноября Волконский простился с королем, который подарил ему золотую табакерку с бриллиантами ценой 500 рублей, и 12 ноября они с Ливеном отправились в обратный путь в Россию ${ }^{26}$.

24 декабря эмиссары прибыли в Петербург.

3 января 1747 г., как сообщил в дневнике Волконский, или 8 января, как датирован отчет, эмиссары подали в Коллегию иностранных дел общий отчет о своей миссии, в котором касались выполнения поставленных им задач по подготовке поляков к нужным России решениям.

Эмиссары констатировали, что большая часть польской шляхты и магнатов при- 
знает, что целостность и вольности Речи Посполитой зависят от России. Поляки опасаются Фридриха II, но и в целом они боятся раздражать своих соседей и предпочтут нейтралитет, а не участие в антипрусских проектах.

Планы увеличения польской армии, по словам Ливена и Волконского, поддерживаются практически всеми польскими дворянами, однако принять это решение на сейме они не могут без ущерба партикулярным интересам, «а все партикулярные интересы публичным предпочитают, потому не чаятельно, чтоб оная аукция армии когда воспоследовала» ${ }^{27}$.

Присоединение Речи Посполитой к союзу Саксонии и России многие поляки считают правильным, но на сейме это решение не было принято по причине того, что он не состоялся, но даже если бы сейм смог работать, то решение все равно бы не прошло «они боятся короля прусского раздразнить», потому ни с кем в союзные обязательства не вступят.

Императорский титул Елизаветы Петровны, по словам эмиссаров, внешне не вызывал никакого затруднения у польских дворян, и, если бы сейм состоялся, решение о нем было бы принято ${ }^{28}$.

Эмиссары дали также краткие характеристики магнатам, из которых можно привести мнения о тех, кто был действительно влиятелен или сыграл в последующем заметную роль в польской политике.

Гетман коронный И. Потоцкий ранее был врагом русских интересов, но теперь резко переменился и сам открыто признает то, что прежнюю политику он оставил и теперь стал ревностен к русским.

Гетман литовский М. Радзивилл, как и предполагалось ранее, - сторонник России и заслуживает определенных подарков со стороны Петербурга.

Князь Август Чарторыйский, воевода русский - «человек весьма честный, и не интерессированный, и умный, великий кредит имеет, сентиментов весьма хороших и к интересам российским весьма усердным находился, желает иметь орден Св. Андрея, о чем уже давно отзывался» ${ }^{29}$.

Станислав Понятовский (отец последнего польского короля того же имени) - «весьма умный», имеет великий кредит в Польше, ранее принадлежал партии Станислава Лещинского, теперь стоит за российские интересы. На него эмиссары указывали как на человека, удержать которого в пророссийской партии нужно обязательно, ибо он состоит в свойстве с семьей Чарторыйских (жена Понятовского Констанция была сестрой А. Чарторыйского, Волконский посетил ее дважды $\left.{ }^{30}\right)$ и «наисильнейшую партию в Короне (собственно Польше. - M.А.) и Литве имеет» ${ }^{31}$, потому ему и его жене нужно оказывать особые знаки российского внимания.

Ставший великим коронным канцлером во время миссии Ливена и Волконского граф Ян Малаховский - человек неглупый, предан королевской партии и не имеет большого влияния в республике.

Подканцлер литовский князь Михаил Чарторыйский, брат Августа, воеводы русского, - «весьма человек умный и дельный, кредит великий имеющий и купно с братом своим, воеводою русским, и зятем, воеводою Понятовским, великую партию имеет, прежде бывал станиславовской партии, а ныне себя к нашей стороне весьма усердным показывал. И для его удержания в нашей стороне потребно хорошим презентом почтить» ${ }^{32}$.

Эмиссары резюмировали, что указали многих магнатов, которых следует привязать к русским интересам, «ибо всегда как нам, так и впредь, сильную партию в Польше чрез то иметь можно» ${ }^{33}$.

Русский двор распорядился передать отчет Ливена и Волконского в русскую миссию при польском дворе для его оценки дипломатами. Российский посланник граф М.П. Бестужев-Рюмин 6 июля 1747 г. ответил, что рапорт эмиссаров составлен по его советам и с общего согласия, поэтому он может только дополнить его. Канцлер Залуский, хотя и богат, не откажется от русской «пенсии» в 6 тыс. рублей, гетман М. Радзи- 
вилл просил у русских в долг 50 тысяч рублей, предлагая в заклад Шаули с окрестностями. М. Бестужев-Рюмин предлагал согласиться на это, взять залог, а «интересы тех денег упустить» ${ }^{34}$ - то есть деньги можно не требовать обратно и превратить их в «пенсион». Посланник отмечал, что Ржевуский, воевода подольский, всегда был за Россию и обижался, что в Петербурге его не оценили по заслугам. Граф Браницкий может быть коронным гетманом в случае смерти престарелого И. Потоцкого, а Ржевуский может занять место польного гетмана, эти идеи можно внушить кому следует от имени российской императрицы.

Миссия Ливена и Волконского в Речь Посполитую в 1746 г. сыграла очень важную роль в формировании русской политики в Польше. Изменившаяся система международных отношений в Европе, в которой одно из ведущих мест заняла набирающая мощь Пруссия, потребовала от русского двора и корректировки своей политики в шляхетской республике. Прежняя линия на то, что в Речи Посполитой следует добиваться сохранения внутренней и внешней слабости, была частично пересмотрена в сторону попытки превратить Польско-литовское государство в одного из участников своеобразного антипрусского «барьера» (при этом традиционно сохраняя слабость других государственных органов шляхетской республики), для чего было необходимо согласиться на планы увеличения польской армии, чтобы она в случае вторжения в Речь Посполитую прусских армий была способна хотя бы продержаться до подхода русских и австрийцев - все же поляки, как считали в Петербурге, должны защищать свою страну и сами.

Эта корректировка русской политики действительно означала смену традиционной петровской линии в отношении Польши, и мнение 3. Зелиньской, отрицающей эту корректировку, не может быть принято. Рост прусского могущества превратил Берлин в главного противника Петербурга, борьбе с которым была подчинена вся внешняя политика Елизаветы Петровны с 1745 г., и это закономерно привело Россию и Пруссию к столкновению в Семилетней войне 1756-1763 гг. Политика России в Польше после 1745 г. тоже оказалась подчинена этому магистральному направлению внешнеполитической деятельности русского двора - Речь Посполитая должна была усилить свою армию и присоединиться к союзу Саксонии и Пруссии. Третью цель русской дипломатии в Польше - признание польским сеймом императорского титула Елизаветы Петровны - можно рассматривать в духе обычной елизаветинской политики, направленной на признание всей Европой ее титула - претензии были не только к Польше, правителей и других стран уговаривали это сделать в качестве условия сотрудничества с ними России.

Миссия Ливена и Волконского не может трактоваться как «обманная» - тайные поручения эмиссарам и их работа с польскими магнатами в нужном Петербургу направлении не оставляют для этого никаких аргументов: Россия действительно желала увеличения польской армии и готова была принять Речь Посполитую как субъект договора, а не объект русских соглашений с Саксонией. Такое изменение русской политики было намечено еще в 1744 г., но тогда оно заключалось только в стремлении усилить обороноспособность Польши против возможных планов прусского вторжения в Речь Посполитую в то время, когда Фридрих II уже вел войну с ее королем как курфюрстом Саксонии. В то время, несмотря на настоятельные призывы главы русской дипломатии А.П. Бестужева-Рюмина, Елизавета Петровна отказывалась от антипрусских действий. В конце 1745 г. на совещаниях сановников императрицы при ее непосредственном участии решение о подготовке войны против Пруссии в защиту подвергшейся прусскому вторжению союзной Саксонии было принято, и миссия Ливена и Волконского тоже была следствием этих решений о войне против Пруссии, теперь отложенной до будущего времени и удобного случая. 
Результаты миссии Ливена и Волконского охладили горячие головы в Петербурге - Речь Посполитая была уже сама по себе структурно неспособна стать как участником антипрусского блока из России, Австрии и Саксонии, так и вообще стать субъектом международных отношений. Именно в этой неспособности польско-литовского государства и следует искать причину неудачи русских планов присоединения Речи Посполитой к оборонительному союзу России и Саксонии. Речь Посполитая все равно оставалась слабым государством, раздираемым противоречиями между магнатами, и ее присоединение к антипрусским союзникам ставило ее под удар Пруссии, который сама республика не могла бы отразить. Практически все шляхтичи и магнаты, по словам русских эмиссаров, боялись Пруссии, и этот страх вынуждал их не делать никаких антипрусских движений, чтобы не спровоцировать соседа, которому, как уже знала вся Европа, для вторжения к соседу был достаточен любой повод. Речь Посполитая предпочла бы остаться вне союзов с теми, кто был врагом Пруссии. Эту политику проводила не только Польша - это было уделом и других слабых государств, знавших, что они не смогут противостоять Пруссии. Сама Саксония, отчаянно желая сокрушения столь страшного ей соседа, так и не присоединилась к антипрусскому союзу России и Австрии 1746 г. вплоть до 1756 г., когда прусские войска, начав Семилетнюю войну, вторглись в Саксонию и оккупировали курфюршество.

Боязнь спровоцировать прусское вторжение привела поляков, подавляющее большинство которых желало бы увеличить свою армию, к отказу от этого намерения. Внутриполитическая нестабильность и наличие множества группировок, отстаивать интересы которых с оружием в руках считалось священным правом польских дворян, заставили как королевский двор, так и польских магнатов отказаться от планов принятия решения об увеличении армии в обход недееспособного сейма - путем образования конфедерации при короле. Фридриху II достаточно было любой группировки несогласных с этим шляхтичей, чтобы со своей армией выступить в их поддержку, ссылаясь на «сохранение польских вольностей» и свой союзный договор с Россией 1743 г., по которому обе стороны гарантировали эти вольности Польше.

Миссия Ливена и Волконского стала рубежом в российской политике в отношении Речи Посполитой. Не подлежат сомнению намерения Петербурга превратить Речь Посполитую в одного из участников антипрусской коалиции. Но после возвращения в Россию этих эмиссаров в Петербурге больше не имели никаких надежд на какое-либо участие шляхетской республики в антипрусских действиях. Уделом Польши в русских планах стало сохранение ее слабости. Опорой для этого должна была стать «русская партия» в стране, кандидатуры для которой были предложены эмиссарами.

До миссии Ливена и Волконского в Петербурге вообще практически не уделяли внимания вопросу создания в Речи Посполитой группировки своих сторонников из влиятельных магнатов - упор во взаимоотношениях двух стран делался на взаимодействии с королевским двором. В Петербурге явно не следили за изменениями должностей тех, кто ранее был лоялен России, и вообще мало представляли себе расклад политических сил и характеристики основных действующих лиц польской политической арены.

Ливен и Волконский представили кандидатов, и в последующее время со многими из указанных ими магнатами были налажены тесные отношения, некоторым была назначена русская пенсия. Братья Чарторыйские и Понятовский, сформировавшие собственную все более усиливавшуюся группировку «Фамилия» (названную так из-за тесных родственных связей между ее участниками), вплоть до Семилетней войны стали главной опо- 
рой Петербурга в Польше. «Фамилия» не была марионеточной русской партией, Чарторыйские, как одни из самых богатых людей Речи Посполитой, не получали русские «пенсии» и не нуждались в них. Внешнеполитический вектор «Фамилии» просто совпал с русскими планами. Именно Пруссия представлялась польским политикам куда более опасным соседом, чем Россия Елизаветы Петровны, не угрожавшая захватом польско-литовских земель и не планировавшая посадить на польский престол полностью зависимого от русских человека. Несмотря на все сложности политики России в польских делах в годы Семилетней войны, когда прежние контакты с «Фамилией», вступившей в противостояние с королевским двором Августа III, русскими дипломатами были прекращены, ни Чарторыйские, ни кто-либо другой так и не стали провозглашать опору на прусского короля Фридриха II, что отметил еще польский историк В. Конопчиньский ${ }^{35}$.

После смерти Елизаветы Петровны новый император Петр III стал отходить от сближения с саксонским двором, испытывая к нему неприязнь, но окончательно саксонских политиков лишила надежд остаться в Речи Посполитой и после смерти Августа III уже Екатерина II. Племянник Чарторыйских и сын С. Понятовскогостаршего, бывший любовник Екатерины Станислав Понятовский-младший станет русским кандидатом на польский престол, которого утвердят на нем русские войска, и он же станет последним королем Речи Посполитой, территории которой поделят между собой примирившиеся друг с другом Пруссия, Россия и Австрия.

\section{ПРИМЕЧАНИЯ}

${ }^{1}$ Zielińska Z. Rosja wobec polskich prób reform w latach 1738-1744 // Studia z dziejów stosunków polsko-rosyjskich w XVIII wieku. Warszawa, 2001. S. 9-12.

${ }^{2}$ Бумаги князя М.Н. Волконского // Русский архив. 1865. № 9. Стб. 1042-1047.
${ }^{3}$ Волконский М.Н. Журнал жизни и службы князя Михаила Никитича Волконского // Российский Архив: История Отечества в свидетельствах и документах XVIII - XX вв. Альманах. T. XIII. М., 2004. C. 9-60.

${ }^{4}$ Там же. С. 23.

5 Дневник докладов Коллегии иностранных дел. 1746 г. // Архив князя Воронцова. Кн. 7. М., 1875. C. 2.

${ }^{6}$ Там же. С. 7-8.

${ }^{7}$ Архив внешней политики Российской империи (далее - АВПРИ). Ф. 74 (Сношения России с Пруссией). Оп. 1. 1745 г. Д. 12. Л. 12; Дневник докладов Коллегии иностранных дел... С. 9.

${ }^{8}$ Там же. С. 35.

${ }^{9}$ АВПРИ. Ф. 79 (Сношения России с Польшей). 1746-1747 гг. Д. 9. Л. 1.

${ }^{10}$ Там же. Л. 4об.

11 Дневник докладов... С. 49.

${ }^{12}$ Там же. С. 50.

${ }^{13}$ Zielińska Z. Rosja wobec polskich prób reform... S. 9-59.

${ }^{14}$ АВПРИ. Ф. 79 (Сношения России с Польшей). 1746-1747 гг. Д. 9. Л. 16-34.

${ }^{15}$ Там же. Л. 158об.

16 Там же. Л. 159об.

${ }_{17}^{17}$ Там же. Л. 169-170.

18 Там же. Л. 165-165об.

${ }^{19}$ Там же. Л. 178об.-179.

${ }^{20}$ Волконский М.Н. Журнал жизни и службы... С. 43.

${ }^{21}$ АВПРИ. Ф. 79 (Сношения России с Польшей). 1746-1747 гг. Д. 9. Л. 181-182об.

22 Там же. Л. 193-193об.

${ }^{23}$ Волконский М.Н. Журнал жизни и службы... С. 43.

${ }^{24}$ АВПРИ. Ф. 79 (Сношения России с Польшей). 1746-1747 гг. Д. 9. Л. 183об.-185об.

${ }^{25}$ Там же. Л. 196-197об.

${ }^{26}$ Волконский М.Н. Журнал жизни и службы... C. 44.

${ }^{27}$ АВПРИ. Ф. 79 (Сношения России с Польшей). 1746-1747 гг. Д. 9. Л. 212об.

${ }^{28}$ Там же. Л. 213-213об.

${ }^{29}$ Там же. Л. 217.

${ }^{30}$ Волконский М.Н. Журнал жизни и службы... С. 43.

${ }^{31}$ АВПРИ. Ф. 79 (Сношения России с Польшей). 1746-1747 гг. Д. 9. Л. 219.

32 Там же. Л. 220об.

33 Там же. Л. 221об.

${ }^{34}$ Там же. 1747 г. Д. 6. Л. 199об.

${ }^{35}$ Konopczyński $W$. Polska w dobie wojny siedmioletniej. T. 1. Kraków-Warszawa, 1909. S. 106. 


\title{
THE RUSSIAN PLANS OF STRENGTHENING OF THE POLISH-LITHUANIAN COMMONWEALTH IN 1746: POLISH MISSION OF M. LIEWEN AND M.N. VOLKONSKY
}

\author{
(c) 2020 M.Yu. Anisimov
}

\section{Institute of Russian History of the Russian Academy of Sciences, Moscow}

In 1746 in the Polish-Lithuanian Commonwealth the next seym (parliament) on which the Polish Royal Court decided to pass the decision on increase in the Polish army limited during Great Northern war had to be called. Strengthening of Prussia was one of the main reasons of emergence of this plan. It threatened with power annexation of the western Polish territories by Berlin. In St. Petersburg where Elizabeth Petrovna's government was also anxious with growth of power of Prussia, decided to support the Polish plans and to turn Poland into the ally of Russia in anti-Prussian fight. For training of the Polish magnates and to clarification of opportunities of the organization of the pro-Russian party, the Russian emissaries $\mathrm{M}$. Liewen and M.N. Volkonsky were sent to Poland. On return to Russia emissaries reported that, despite fears of Prussia, Poles are not ready to take any steps provoking it, including increase in army. Also emissaries presented candidacies of the magnates capable to be active supporters of Russia. From now on the Russian Court, having refused the idea of strengthening of the Polish-Lithuanian Commonwealth, did not lose sight of an internal political situation in Poland any more and supported the influential group of princes Czartoryski's which was guided by rapprochement with Russia.

Keywords: Elizabeth Petrovna, Russian-Polish relations, foreign policy of Russia, PolishLithuanian Commonwealth.

DOI: $10.37313 / 2658-4816-2020-2-4-79-92$

Maxim Anisimov, Candidate of History, Senior

Researcher.E-mail: anisimovm@list.ru 